\title{
Pilot Study on Students in Islamic Boarding Schools to Measure the Reliability and Validity of The Self-Regulation Scale
}

\author{
Reliabilitas dan Validitas Skala Regulasi Diri pada Siswa di Asrama Islam (Pilot Study)
}

Shonia Dwiasa Pangukir ${ }^{1}$, Dyah Astorini Wulandari ${ }^{2}$

${ }^{1}$ Universitas Muhammadiyah Purwokerto, Purwokerto, Indonesia

\begin{abstract}
ARTICLE INFO
Article history:

DOI:

$\underline{10.30595 / \mathrm{pssh} . v 2 \mathrm{i} .108}$

Submitted: Jul 09, 2021

Accepted: Aug 30, 2021

Published: Sept 24, 2021

ABSTRACT

This study aims to conduct a trial to determine the validity and reliability of the selfregulation scale and determine what dimensions/aspects are considered capable of forming self-regulation variables. Validity and reliability tests are carried out to determine a measuring instrument's level of accuracy and consistency. This selfregulation variable is measured by the seven dimensions of Miller \& Brown (Neal \& Carey, 2005), namely receiving, evaluating, triggering, searching, formulating, implementing, and assessing. Thirty-six students at Islamic boarding school $\mathrm{X}$ in Banyumas, Indonesia, were involved as participants. Analysis of the data used to measure validity using the corrected item-total correlation formula and reliability using Cronbach's alpha, which was analyzed using SPSS version 25. The analysis results prove that from the seven dimensions of self-regulation, there are 25 valid items and have a reliability coefficient of 0.908 . Thus, the self-regulation scale can be used for research.
\end{abstract}

This work is licensed under a Creative Commons Attribution 4.0 International License.

Keywords:

Reliability, Validity, Self-

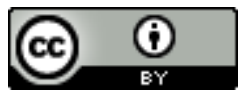

Regulation, Students

Corresponding Author:

Shonia Dwiasa Pangukir

Universitas Muhammadiyah Purwokerto, Purwokerto, Indonesia

Email: shoniadwiasa00@gmail.com

\section{INTRODUCTION}

Learning is a process carried out to gain various competencies, skills, and attitudes obtained gradually and continuously from infancy to old age through a series of lifelong learning processes. The learning processes are carried out through involvement and participation in formal education and non-formal education (Bell-Gredler, 1986). Realizing how important it is to study religion or science, many individuals are motivated to look at a boarding school. Pesantren itself is a unique institution with robust and sticky characteristics (Zuhriy, 2011). This is because Islamic boarding schools have a different concept from educational institutions in general, namely providing dormitories and the same number of Islamic subjects or even more than other educational institutions.

Santri who study in Islamic boarding schools are between 13-19 years old and coincide with adolescence (Prasetyana \& Mariyati, 2020). Erickson's psychosocial theory states that adolescence to adulthood is a period of self-discovery that includes biological processes. Cognitive and socio-emotional changes (Santrock, 2004). Therefore, it is necessary to have good self-regulation because it is the basis of the socialization process and is related to all physical, cognitive, and socio-emotional development (Papalia \& Olds, 2001).

In this study, validity and reliability tests were carried out. A validity test is a statistical test to test the ability of research instruments (such as questionnaires) in measuring a variable. Of course, instrument testing was not carried out on the population, but respondents outside the research target, and only 30 people were sufficient. This number relates to the start of the r-table value not changing after the number 30 (Harrington, 2009).

Reliability means that reliability is the accuracy and precision of a measuring instrument in a measurement procedure. The reliability coefficient indicates the stability of the scores obtained by the individual, which reflects 
the process of reproducing scores. The score is called stable if the score is received at one time and the results are relatively the same at other times. Another meaning of reliability in terms of stability is that the subject to measurement will rank relatively the same in independent testing with equivalent test equipment (Widodo, 2006).

\section{THEORITICAL FRAMEWORK}

Miller \& Brown (1991) stated that self-regulation is the ability of individuals to design, guide, and observe their behavior in achieving. Then Brown added that self-regulation is a person's ability to guide and keep his behavior to achieve goals involving cognitive, physical, social, and emotional elements. This is in line with Friedman \& Schustack's statement (Ahmar, 2016) that self-regulation is the ability of individuals to plan goals and actions on arranged terms, evaluate their success when achieving these targets, and reward themselves if these goals are achieved.

This self-regulation is not born but can be learned (McCullough \& Willoughby, 2009). This is in line with Suryani's statement (Ghufron \& Risnawita, 2012)that self-regulation is a process or self-instruction of individuals to change their mental abilities into skills in the form of activities. Self-regulation can be seen as a psychological process that can determine a person to take action; the mechanism in each individual can be arranged to produce positive behavior to achieve the desired goals (Dias \& Castillo, 2014).

Another definition states that self-regulation is a conceptualization of controlling and directing individual actions or behavior in achieving goals (Carver \& Scheier, 1998). Bandura (Alwisol, 2009) also states that selfregulation is a person's ability to control his behavior and maintain his commitment to a goal over a certain period. This self-regulation refers to thoughts, feelings, and actions planned by the self and continuously achieving goals (Zimmerman, 2000).

According to Miller \& Brown (Neal \& Carey, 2005), self-regulation theory has seven aspects: receiving, evaluating, triggering, searching, formulating, implementing, and assessing. First, receiving is an individual's first step in receiving information from various sources. With this information, individuals can find out more specific characters. Next, do an evaluation that is realizing how big the problem is. This self-evaluation process requires individuals to analyze information by comparing outside problems with personal opinions from previous similar experiences. Next, make changes, namely comparing the results of earlier evaluations to create positive or negative feelings.

Individuals avoid attitudes or thoughts that are not by the information obtained with existing norms. All reactions that occur at this stage are also called tendencies towards change. The previous step of the evaluation process causes emotional reactions and attitudes. At the end of the evaluation process, it shows the conflict between individual perspectives in understanding the problem and then looking for a way out of the difficulties faced called searching or finding solutions.

Hereafter, to continue achieving goals or objectives, such as time issues, development activities, places, and other aspects that can support efficiency and effectiveness, is called formulating or designing plans. Then, establish procedures or implementing, which lead to actions or take appropriate steps that lead to goals and modify attitudes as desired in the process. Last, called assessment or the effectiveness of the plan, can assist in determining and realizing whether the programs that are not recognized are as expected or not and whether the results obtained are as expected.

Then the factors that can affect self-regulation are internal and external (Alwisol, 2009). Internal factors come from within the individual, such as self-observation, the assessment process, and self-reaction. Selfobservation is done based on quality factors, appearance quantity appearance, originality of self-behavior, and so on. People should monitor their performance, even if not ideal, because people prefer certain aspects of behavior over others. What a person observes depends on his interests and self-concept. Then, the assessment process this process is intended to help someone in controlling their behavior. A person can realize himself reflectively and judge how valuable a person's actions are based on the goals that have been made. This appraisal process relies on personal standards, referral performance, scoring activities, and attributions to version. Last, self-reaction is by giving a positive or negative response to behavior depending on how the behavior appears influenced by personal standards.

In addition to internal factors, external factors include environmental factors such as the opportunity to selfregulate and the availability of learning resources (Pintrich, 1991). Then there are other forms of reinforcement, such as holding awards as behavior reinforcement for specific purposes (Dami \& Parikaes, 2018). Based on the description above, it can be concluded that self-regulation is an individual's ability to regulate, control, plan, direct, and monitor behavior by involving cognitive, physical, social, and emotional elements to achieve goals.

\section{RESEARCH METHODOLOGY}

The preliminary study was conducted using a qualitative method via google form on 22 respondents. The questions asked were about making decisions to study at Islamic Boarding Schools, adapting, and the problems that occurred, both with the Islamic Boarding School environment and with colleagues at Islamic Boarding Schools. These respondents are teenagers who decide their choice to continue their education in Islamic boarding schools. Eleven out of 22 respondents answered that the decision to enter an Islamic boarding school was of their own volition, 8 of 22 respondents answered that entering a boarding school was the desire of their parents, and 3 of 22 respondents answered that entering a boarding school was a mutual desire. 
The questions given to the respondents were about the reasons for choosing the Islamic boarding school, then how it felt to study at the Islamic boarding school and what difficulties were experienced while at the Islamic boarding school. It was found that the respondents chose Islamic boarding schools because from the beginning, they were directed to study at pesantren (Islamic boarding school). Another answer stated a desire among the respondents to enter Islamic boarding schools that were considered more capable of teaching Islamic education.

In this study, 36 female Islamic boarding school students aged 13-17 years in Banyumas, Indonesia, participated. The data collection method used in this pilot study was carried out by providing a self-regulation scale.

This experimental study aims to measure the validity and reliability of Miller \& Brown's self-regulation The Self Regulation Questionnaire (SRQ) scale, adapted by (Fatmawati, 2018). In conducting the validity test, the product-moment formula will be used, while for measuring reliability, Cronbach's alpha technique will be used. Both will be done with the help of SPSS version 25 .

Item selection using a method using the item correlation formula, by correlating the score of the questions with the total score of the construct or variable. An item can be said to be valid with a significance level of 5\%.

While this reliability test was carried out using Cronbach's alpha formula. A constructor variable is reliable if it gives a Cronbach's alpha value $>0.70$ (Ghozali, 2018).

\section{RESULTS AND DISCUSSION}

Tabel 1. BluePrint of self-regulation before analysis.

\begin{tabular}{ccccc}
\hline No & Aspects & Favorable & Unfavorable & Total \\
\hline $\mathbf{1 .}$ & Receiving & $1,22,36,57$ & $8.15,29,43,50$ & $\mathbf{9}$ \\
$\mathbf{2 .}$ & Evaluating & $9,16,23,30,44,51,58$ & 2,37 & $\mathbf{9}$ \\
$\mathbf{3 .}$ & Triggering & $17,28,52,59$ & $3,10,24,31,45$ & $\mathbf{9}$ \\
$\mathbf{4}$ & Searching & $11,18,25,32,39,46,53,60$ & 4 & $\mathbf{9}$ \\
$\mathbf{5 .}$ & Formulating & $47,54,61$ & $5,12,19,26,33,40$ & $\mathbf{9}$ \\
$\mathbf{6 .}$ & Implementing & $27,34,41,48$ & $6,13,20,55,62$ & $\mathbf{9}$ \\
$\mathbf{7 .}$ & Assessing & $7,14,28,38,42,49,56$ & 21,63 & $\mathbf{9}$ \\
\hline & TOTAL & $\mathbf{3 7}$ & $\mathbf{2 6}$ & $\mathbf{6 3}$ \\
\hline
\end{tabular}

Table 1 above is a blueprint for the self-regulation scale before calculating the psychometric analysis. The variable of self-regulation in Islamic boarding school students was measured using 63 statement items consisting of 37 favorable and 26 unfavorable items.

Tabel 2. The result of the item analysis of the self-regulation scale

\begin{tabular}{lccccc}
\hline & \multicolumn{5}{c}{ Item-Total Statistics } \\
& $\begin{array}{c}\text { Scale Mean if } \\
\text { Item Deleted }\end{array}$ & $\begin{array}{c}\text { Scale Variance if } \\
\text { Item Deleted }\end{array}$ & $\begin{array}{c}\text { Corrected Item- } \\
\text { Total } \\
\text { Correlation }\end{array}$ & $\begin{array}{c}\text { Cronbach's } \\
\text { Alpha if Item } \\
\text { Deleted }\end{array}$ & Information \\
\hline ITEM00001 & 80,1111 & 209,816 &, 339 &, 908 & Valid \\
ITEM00004 & 80,6944 & 202,961 &, 447 &, 907 & Valid \\
ITEM00011 & 80,5278 & 204,942 &, 557 &, 904 & Valid \\
ITEM00012 & 80,8611 & 214,466 &, 367 &, 910 & Valid \\
ITEM00018 & 80,0000 & 201,143 &, 632 &, 902 & Valid \\
ITEM00021 & 80,1389 & 198,809 &, 728 &, 901 & Valid \\
ITEM00022 & 80,3056 & 204,675 &, 406 &, 907 & Valid \\
ITEM00025 & 80,5278 & 205,685 &, 510 &, 905 & Valid \\
ITEM00028 & 81,2778 & 196,435 &, 688 &, 901 & Valid \\
ITEM00029 & 79,7778 & 201,949 &, 529 &, 904 & Valid \\
ITEM00033 & 80,6944 & 206,275 &, 339 &, 909 & Valid \\
ITEM00034 & 80,2778 & 209,806 &, 355 &, 908 & Valid \\
ITEM00035 & 80,1111 & 200,730 &, 783 &, 900 & Valid \\
ITEM00036 & 79,9722 & 210,771 &, 362 &, 907 & Valid \\
ITEM00042 & 80,5000 & 210,486 &, 405 &, 907 & Valid \\
ITEM00043 & 80,7778 & 197,663 &, 621 &, 902 & Valid \\
ITEM00047 & 79,7778 & 200,521 &, 743 &, 901 & Valid \\
ITEM00048 & 80,4722 & 205,171 &, 554 &, 904 & Valid \\
ITEM00049 & 80,1667 & 204,143 &, 480 &, 905 & Valid \\
ITEM00052 & 80,1111 & 199,644 &, 611 &, 903 & Valid \\
ITEM00054 & 80,2222 & 206,463 &, 472 &, 905 & Valid \\
ITEM00057 & 79,8333 & 204,257 &, 582 &, 904 & Valid \\
ITEM00058 & 80,3056 & 204,161 &, 563 &, 904 & Valid \\
ITEM00059 & 79,5278 & 208,942 &, 391 &, 907 & Valid \\
ITEM00062 & 80,3611 & 200,923 &, 530 &, 904 & Valid \\
\hline
\end{tabular}

Proceedings homepage: https://conferenceproceedings.ump.ac.id/index.php/pssh/issue/view/7 
The results of the item-total correlation analysis are shown in Table.2. If the corrected item-total correlation is more than 0.3 , the item has discriminant power, which means that the thing can distinguish the high score on the self-regulation scale or the low one. So from the validity test results obtained, as many as 25 valid items can be used to measure self-regulation variables. The corrected item-total correlation coefficient moves from 0.339 to 0.783.

\begin{tabular}{|c|c|c|c|c|c|c|}
\hline \multirow[t]{2}{*}{ No } & \multirow[t]{2}{*}{ Aspects } & \multicolumn{2}{|c|}{ Favorable } & \multicolumn{2}{|c|}{ Unfavorable } & \multirow[t]{2}{*}{ Total } \\
\hline & & Valid & Not & Valid & Not & \\
\hline 1. & Receiving & $1,22,36,57$ & - & 29,43 & $8,15,50$ & 9 \\
\hline 2. & Evaluating & 58 & $9,16,23,30,44,51$ & - & 2,37 & 9 \\
\hline 3. & Triggering & $28,52,59$ & 17 & - & $3,10,24,31,45$ & 9 \\
\hline 4. & Searching & $11,18,25$ & $32,39,46,53,60$ & 4 & - & 9 \\
\hline 5. & Formulating & 47,54 & 61 & 12,33 & $5,19,26,40$ & 9 \\
\hline 6. & Implementing & 34,48 & 27,41 & 62 & $6,13,20,55$ & 9 \\
\hline 7. & Assessing & $28,42,49$ & $7,14,38,56$ & 21 & 63 & 9 \\
\hline & Total & 18 & 19 & 7 & 19 & 63 \\
\hline
\end{tabular}

The table above shows that the item-total self-regulation scale correlation results showed 25 valuable items consisting of 18 favored items and seven disliked items.

\begin{tabular}{cc}
\multicolumn{2}{c}{ Tabel. 4 Realibility test result } \\
\hline \multicolumn{2}{c}{ Reliability Statistics } \\
\hline Cronbach's Alpha & N of Items \\
\hline, 908 & 25 \\
\hline
\end{tabular}

Reliability Test Results The self-regulation scale of Islamic boarding school students shows a reliability coefficient of 0.908 . These results indicate that the reliability coefficient is more significant than 0.70 . A constructor variable is said to be reliable if it gives a Cronbach alpha value $>0.70$.

From these results, it can be concluded that the self-regulation instrument used is reliable. This means that the tool can be said to have high accuracy or consistency in measuring self-regulation variables. And for that, based on the results of validity and reliability tests, this self-regulation instrument can be used by other researchers to measure self-regulation.

After doing the validity test on the self-regulation scale, below will be explained the valid variables on the self-regulation scale, namely:

\begin{tabular}{|c|c|c|}
\hline & $\begin{array}{l}\text { Corrected Item-Total } \\
\text { Correlation }\end{array}$ & Informat \\
\hline $\begin{array}{l}\text { I usually keep track of progress towards my goals } \\
\text { (Saya biasanya terus memantau perkembangan menuju tujuan saya) }\end{array}$ & ,908 & Valid \\
\hline $\begin{array}{l}\text { I doubt I can change anything even if I want to } \\
\text { (Saya ragu dapat mengubah sesuatu meskipun saya menginginkannya) }\end{array}$ & ,907 & Valid \\
\hline $\begin{array}{l}\text { I can complete the goals that I set for myself } \\
\text { (Saya mampu menyelesaikan tujuan- tujuan yang saya tetapkan untuk } \\
\text { diri saya sendiri) }\end{array}$ & ,904 & Valid \\
\hline $\begin{array}{l}\text { I procrastinate in making decisions } \\
\text { (Saya menunda-nunda dalam membuat keputusan) }\end{array}$ & ,910 & Valid \\
\hline $\begin{array}{l}\text { When I want to change, I'm confident that I can } \\
\text { (Ketika saya ingin berubah, saya percaya diri bahwa saya bisa) }\end{array}$ & ,902 & Valid \\
\hline $\begin{array}{l}\text { I don't seem to learn from my mistakes } \\
\text { (Saya tampaknya tidak belajar dari kesalahan-kesalahan saya) }\end{array}$ & ,901 & Valid \\
\hline $\begin{array}{l}\text { I usually take care not to overdo it while working, eating, and drinking } \\
\text { (Saya biasanya berhati- hati untuk tidak berlebihan saat bekerja, } \\
\text { makan dan minum) }\end{array}$ & ,907 & Valid \\
\hline $\begin{array}{l}\text { I've been looking for suggestions for change information } \\
\text { (Saya sudah mencari saran-saran informasi perubahan) }\end{array}$ & ,905 & Valid \\
\hline $\begin{array}{l}\text { I usually only need one mistake to learn a lesson } \\
\text { (Saya biasanya hanya membutuhkan satu kali kesalahan untuk dapat } \\
\text { mengambil sebuah pelajaran) }\end{array}$ & ,901 & Valid \\
\hline $\begin{array}{l}\text { I don't take lessons well from a punishment } \\
\text { (Saya tidak mengambil pelajaran dengan baik dari sebuah hukuman) }\end{array}$ & ,904 & Valid \\
\hline $\begin{array}{l}\text { I have trouble setting goals for myself } \\
\text { (Saya kesulitan menetapkan tujuan untuk diri saya sendiri) }\end{array}$ & ,909 & Valid \\
\hline I have a strong determination & ,908 & Valid \\
\hline
\end{tabular}

Proceedings homepage: https://conferenceproceedings.ump.ac.id/index.php/pssh/issue/view/7 
(Saya mempunyai tekad yang kuat)

When I try to change something, I pay close attention to how I do it

,900

Valid

(Ketika saya mencoba mengubah sesuatu, saya memperhatikan betul

bagaimana saya mengerjakannya)

I usually judge what I'm doing by the consequences of what I'm doing

(Saya biasanya menilai apa yang saya sedang kerjakan melalui akibat-

Valid

akibat dari apa yang saya kerjakan)

I got goals for myself and keep track of progress

(Saya menetapkan tujuan untuk diri saya dan terus memantau

Valid

perkembangannya)

I often don't pay attention to what I'm doing

(Saya seringkali tidak memperhatikan apa yang sedang saya lakukan)

When I have a goal, I can usually plan how to achieve it

(Ketika saya mempunyai tujuan, saya biasanya bisa merencanakan

bagaimana untuk mencapainya)

I have rules that I obey no matter what

(Saya mempunyai peraturan yang saya patuhi apapun yang terjadi)

If I resolve to change something, I pay attention to how I do it

Valid

(Jika saya membuat sebuah resolusi untuk mengubah sesuatu, saya

Valid

sangat memperhatikan bagaimana saya melakukannya)

Usually, I know the need for a change before others know about it

(Biasanya saya mengetahui perlunya sebuah perubahan sebelum orang lain mengetahuinya)

I usually think before I act

(Saya biasanya berpikir sebelum saya bertindak)

I learn from my mistakes

(Saya belajar dari kesalahan-kesalahan saya)

I know how I will

(Saya tahu saya akan bagaimana)

I get annoyed when things don't go the way I want

, 904

Valid

(Saya merasa terganggu ketika banyak hal terjadi tidak seperti yang

saya inginkan)

I give up easily

(Saya mudah menyerah)

Valid

Valid

Valid

Valid

,904

Valid

,907

Valid

A reliable instrument was obtained from the item analysis and reliability test of the self-regulation scale, and there were 25 valuable items. The self-regulation scale consists of 25 items, namely six items on the receiving aspect, 1 item on the evaluation aspect, three items on the trigger aspect, four items on the search aspect, four items on the formulating aspect, three items on the implementing aspect, and four items on the aspect of assessment. This instrument can be used to measure the self-regulation of Islamic boarding school students.

The self-regulation scale used is Miller \& Brown's Self-regulation Questionnaire scale adapted by (Fatmawati, 2018). It started with 63 items, but 24 items needed to be dropped after the pilot study. The 24 invalid items have a coefficient value of less than 0.3 . Meanwhile, 39 valuable items were obtained with a coefficient value of more than 0.3. The correlation coefficient for selected items ranges from 0.304 to 0.658 .

The reliability test was carried out using the Cronbach Alpha formula. A constructor variable is reliable if it gives a Cronbach's alpha value $>0.70$ (Nunnaly in Ghozali, 2018). And based on the reliability test, the Cronbach's Alpha value was 0.908 , indicating that the Cronbach's Alpha value obtained is more significant than 0.70 or $0.908>$ 0.70 .

The description shows that the scale of self-regulation in Islamic boarding school students can be used as a basis for conducting research. This study has limitations because it only involved 36 students. Future researchers can validate this measuring instrument with more diverse participants.

Respondents experienced difficulties in self-regulation to achieve targets, both in terms of lessons and in daily activities. Respondents also stated that the number of moves made it difficult for them to organize themselves to carry out the actions appropriately. The existence of conflicts with friends around an incompatibility with the condition makes individuals less free to actualize themselves, thus inhibiting self-regulation. This is similar to what one of the dormitory supervisors and teachers said that respondents are often less able to self-regulate. There are still frequent conflicts with friends, and they feel uncomfortable.

In addition, school lessons every day are also considered to provide difficulties for respondents. The excessive number of general and religious subjects makes respondents less likely to get satisfactory results. Another activity required by Islamic boarding schools is "tahfidz" Al-Quran, with specific targets every semester. However, this target is often not achieved every semester.

These respondents are teenagers who decide their choice to continue their education in Islamic boarding

Proceedings homepage: https://conferenceproceedings.ump.ac.id/index.php/pssh/issue/view/7 
schools. Eleven out of 22 respondents answered that the decision to enter a boarding school was of their own volition; eight of 22 respondents answered that entering a boarding school was their parents' desire. Three of 22 respondents answered that entering a boarding school was a mutual desire.

\section{CONCLUSION}

From the results of the psychometric analysis that has been carried out, it can be concluded that the selfregulation scale measuring instrument compiled in this study can be classified into reliable criteria for students, especially for boarding school students. The advantage of this measuring tool is its context which is specific to

"santri." The reliability is 0.908 , and the corrected item-total correlation value moves from 0.339 to 0.782 .

This shows quite a slight difference with the trial research conducted by Fatmawati (Fatmawati, 2018). The item-total correlation coefficient for selected items ranges from 0.304 to 0.658 . Based on the reliability test results, Cronbach's Alpha reliability is 0.725 , which means the reliability is categorized as sufficient.

\section{REFERENCES}

Ahmar, D. S. (2016). The relationship between Self Regulation with Creative Thinking Ability of Students in Chemistry Class XI IPA at Takalar. Jurnal Sainsmat, 5(1), 7-23.

Alwisol. (2009). Psikologi Kepribadian. UMM Press.

Bell-Gredler, M. E. (1986). Learning and Instruction. Macmillan Publishing.

Dami, Z. A., \& Parikaes, P. (2018). Regulasi Diri dalam Belajar Sebagai Konsekuen. Jurnal Penelitian Dan Pengembangan Pendidikan, 1(1), 82-95. https://ejournal.upg45ntt.ac.id/ciencias/article/view/19/13

Dias, P., \& Castillo, J. A. G. del. (2014). Self-regulation and Tobacco Use: Contributes of the Confirmatory Factor Analysis of the Portuguese Version of the Short Self-Regulation Questionnaire. Procedia - Social and Behavioral Sciences, 159, 370-374. https://doi.org/10.1016/j.sbspro.2014.12.390

Fatmawati, I. (2018). Hubungan Antara Regulasi Diri dan Resiliensi Pada Remaja di Keluarga Yang Bercerai. In SKRIPSI (dipublikasikan) (Vol. 2). Universitas Islam Indonesia, Yogyakarta.

Ghozali, I. (2018). Aplikasi Analisis Multivariate dengan program IBM SPSS 25. Badan Penerbit Universitas Diponegoro.

Ghufron, M. N., \& Risnawita, R. (2012). Teori-teori Psikologi (Cetakan Ke). AR-RUZZ MEDIA.

Harrington, D. (2009). Confirmatory Factor Analysis. Oxford University Press.

McCullough, M. E., \& Willoughby, B. L. B. (2009). Religion, Self-Regulation, and Self-Control: Associations, Explanations, and Implications. Jurnal American Psychological Association, 135(1), 69-93. https://doi.org/10.1037/a0014213

Miller, W. R., \& Brown, J. M. (1991). Self-regulation as a conceptual basis for the prevention and treatment of addictive behaviours3-79. Self-Control and the Addictive Behaviours, 3-79.

Neal, D. J., \& Carey, K. B. (2005). A follow-up psychometric analysis of the self-regulation questionnaire. Psychology of Addictive Behaviors, 19(4), 414-422. https://doi.org/10.1037/0893-164X.19.4.414

Papalia, D. E., \& Olds, S. W. (2001). Human Development (8th Editio). McGraw-Hill.

Prasetyana, Z., \& Mariyati, L. I. (2020). HUBUNGAN ANTARA RELIGIUSITAS DENGAN REGULASI DIRI. Psyche: Jurnal Psikologi Universitas Muhammadiyah Lampung, 2(2), 76-87.

Santrock, J. W. (2004). Life-Span Development : Perkembangan Masa Hidup (Jilid I). Erlangga.

Widodo, P. B. (2006). Reliabilitas Dan Validitas Konstruk Skala Konsep Diri Untuk Mahasiswa Indonesia. Jurnal Psikologi, 3(1), 1-9. https://doi.org/10.14710/jpu.3.1.1

Zimmerman, B. J. (2000). Attening self-regulation A social cognitive perspective. In Handbook of Self-Regulation (pp. 13-39). San Diego Academic Press.

Zuhriy, M. S. (2011). Budaya Pesantren Dan Pendidikan Karakter Pada Pondok Pesantren Salaf. Walisongo: Jurnal Penelitian Sosial Keagamaan, 19(2), 287-310. https://doi.org/10.21580/ws.2011.19.2.159 